Research Article

\title{
A Case Study of Optimization and Application of Soft-Rock Roadway Support in Xiaokang Coal Mine, China
}

\author{
Shuai Guo $\mathbb{D}^{1},{ }^{1}$ Xun-Guo Zhu $\mathbb{D}^{2},{ }^{2}$ Xun Liu $\mathbb{D}{ }^{3}{ }^{3}$ and Hong-Fei Duan $\mathbb{D}^{4}$ \\ ${ }^{1}$ State Key Laboratory for GeoMechanics and Deep Underground Engineering, China University of Mining and Technology, \\ Xuzhou 221116, China \\ ${ }^{2}$ College of Architectural Engineering, Dalian University, Liaoning, Dalian 116622, China \\ ${ }^{3}$ School of Mines, China University of Mining and Technology, Xuzhou 221116, China \\ ${ }^{4}$ Jinneng Holding Group Co. Ltd., Datong 037000, China
}

Correspondence should be addressed to Xun-Guo Zhu; zhu_xunguo@hotmail.com

Received 11 May 2021; Accepted 28 June 2021; Published 15 July 2021

Academic Editor: Jia Lin

Copyright (c) 2021 Shuai Guo et al. This is an open access article distributed under the Creative Commons Attribution License, which permits unrestricted use, distribution, and reproduction in any medium, provided the original work is properly cited.

The roadway of S2S2 fully mechanized caving face (FMCF) in Xiaokang Coal Mine is one of the most typical deep-buried soft-rock roadways in China and had been repaired several times. In order to figure out the failure reasons of the original roadway support, the geological conditions were investigated, the surrounding rock stress was monitored, the rib displacement, roof separation, and floor heave were in situ measured, and the performance of the U-shaped steel support was simulated. The above analysis results indicated that the support failure was mainly caused by (1) the unreasonable arch roadway section, (2) the high and complex surrounding rock stress, (3) the failure control of the floor heave, and (4) the inadequate self-supporting capacity of the surrounding rock. For optimizing, the roadway section was changed to circle and a new full-section combined support system of "belt-cable-mesh-shotcrete and U-shaped steel-filling behind the support" was adopted, which could specifically control the floor heave, allow the roadway deformation in control, and improve the self-supporting ability and stress field of the surrounding rock. To determine the support parameters, the selected U-shaped steel support was verified by simulation, and various bolt-cable support schemes were simulated and compared. Finally, such an optimized support scheme was applied in the roadway of the next replacement FMCF. The in situ monitoring showed that the rib-to-rib convergence and roof-to-floor convergence were both controlled within $600 \mathrm{~mm}$, which indicated that the roadway was effectively controlled. This case study has important reference value and guiding function for the optimal design of the soft-rock roadway support with similar geological conditions.

\section{Introduction}

As coal mining depth increases, the roadway support is generally faced with the difficult problems caused by soft rock and high ground stress [1-3]. In addition, the severe strata behavior, the large and long-time roadway deformation, serious floor heave, and serious support structure damage lead to over $70 \%$ of the repair rate in such kind of roadways [4-6]. The induced vicious cycle of "digging and repairing" during mining [7-9] wastes a lot of manpower and material, directly affects the efficient production of coal mine, and endangers the safety of human life and property $[10-12]$.
The research on the theory and technology of the softrock roadway support under high ground stress is active, and a series of research results have been obtained. For instance, $\mathrm{He}$ et al. [13] proposed the coupling support concept of roadway and developed the technical system of active support; Kang and Wang [14] put forward the theory of high pretensioned stress and intensive bolting system and developed a complete technology of bolt support for coal mine; Gao et al. [15] developed the concrete-filled steel tube support technology; Jiang et al. [16] analyzed the mechanism of different types of roadway floor heaves and proposed corresponding prevention and control measures. In addition, Yang et al. [17] revealed the deformation and failure 
mechanism of deep soft-rock roadway and put forward a new "bolt-cable-mesh-shotcrete + shell" combined support; Shen [18] optimized the spacing and pretightening force of the bolt and anchor cable by UDEC; Kang et al. [19] analyzed the soft-rock roadway deformation and failure characteristics with different support types by the numerical simulation method; Wang et al. [20] first adopted grouting to enhance the surrounding rock's self-bearing ability and then used the bolt to control the deformation and failure of the soft surrounding rock.

These studies laid the theoretical foundation and provided new ideas and methods for the support of deep-buried softrock roadway. As for specific applications, the geological conditions and the key factors affecting the stability of surrounding rocks are complex and numerous [20-23]. Hence, the design and optimization of the support scheme should be carried out according to the in situ conditions and a suitable support theory and technology should be adopted [24-27].

In Xiaokang Coal Mine, during the first fully mechanized caving face (FMCF) of S1W3, during the whole mining period, the cumulative roof-to-floor convergence of the two mining roadways is $3800 \mathrm{~mm}$ and $6500 \mathrm{~mm}$, respectively, and the cumulative rib-to-rib convergence is $1400 \mathrm{~mm}$ and $3200 \mathrm{~mm}$, respectively, which is 10 20 times and 2 3 times that of other mines where the surrounding rock is relatively stable and soft. Coupled with serious floor heave and complex surrounding rock stress, the soft-rock roadway in Xiaokang Coal Mine is extremely difficult to maintain in China and even in the world [28].

The purpose of this paper is to optimize and design the support scheme of the deep-buried soft-rock roadway in Xiaokang Coal Mine based on the initial soft-rock roadway support system in S2S2 FMCF. Thus, the performance of the original support scheme in S2S2 FMCF was first analyzed by in situ measurement and numerical simulation to figure out the failure mechanism, based on which the corresponding control technology was developed and the support scheme was optimized. Finally, the new proposed support scheme was carried out in the roadway of the next replacement FMCF, and the in situ monitoring was carried out to identify the effect of the new support system.

\section{Engineering Background}

2.1. The Geological Conditions. As shown in Figure 1, Xiaokang Coal Mine with an area of $28.99 \mathrm{~km}^{2}$ is located in Liaoning Province, China. Its north-south length is $6.03 \mathrm{~km}$ and the east-west width is $4.81 \mathrm{~km}$.

In Xiaokang Coal Mine, the S2S2 FMCF and its replacement FMCF are both located in southern No. 2 mining area (S2) and share the same geological conditions. The width of the S2S2 FMCF is $232 \mathrm{~m}$, and the advancing length is $1281 \mathrm{~m}$. As for the coal seam, the thickness is $7.50 \mathrm{~m}$ to $10.24 \mathrm{~m}$, with an average of $8.50 \mathrm{~m}$; the buried depth is $640 \mathrm{~m}$ to $720 \mathrm{~m}$, with an average of $665 \mathrm{~m}$; and the dip is $3^{\circ}$ to $10^{\circ}$, with an average of $5^{\circ}$.

The immediate roof of the coal seam is oil shale with stepped fracture. It is carbonaceous, oil-rich, and easily weathered and would be crushed after drying, which make it not easy to maintain. Its thickness is $6.31 \mathrm{~m}$ to $14.2 \mathrm{~m}$ with an average of $8.5 \mathrm{~m}$. The mining height of the machine is $2.8 \mathrm{~m}$, the coal drawing height is $5.7 \mathrm{~m}$, and the caving ratio is 1 : 2.04. The basic roof is mainly composed of mudstone with obvious beddings and joints. Its thickness is $11.2 \mathrm{~m}$ to $21.3 \mathrm{~m}$ with an average of $15.6 \mathrm{~m}$.

The thickness of the coal seam floor is $6.51 \mathrm{~m}$ to $12.3 \mathrm{~m}$ with an average of $7.62 \mathrm{~m}$. It was relatively highly cemented by argillaceous material. More than $50 \%$ of the clay minerals in floor strata are Aemon interbeds, and the other clay minerals are mainly kaolin and illite, so they are easy to be weathered and have strong dilatability, resulting in a very serious floor heave.

2.2. The Initial Support Scheme. The arch-section mining roadways of the S2S2 FMCF with a sectional area of $13.7 \mathrm{~m}^{2}$ initially adopted the combined support scheme of "boltmesh-shotcrete and U-shaped steel". The specific support parameters are as follows.

As shown in Figure 2(a), the anchor bolts were just installed at the top and shoulder of the roadway. The anchor bolt used the thread steel of M22 $\times 2400 \mathrm{~mm}$ with a spacing of $800 \times 800 \mathrm{~mm}$ and a pretightening force of $60 \mathrm{kN}$. The lengthened resin anchorage was applied with two Z2335 resin anchor agents and one Z2540 resin anchor agent in each hole. The high-intensity tray of $120 \mathrm{~mm} \times 120 \mathrm{~mm} \times 10 \mathrm{~mm}$ was selected. The U36 steel support was adopted with a spacing of $1000 \mathrm{~mm}$. The rhombic metal mesh was used with a bar of $8 \mathrm{~mm}$ and a grid spacing of $100 \mathrm{~mm}$. The back-filling thickness was $300 \mathrm{~mm}$. There almost no support was conducted to control the floor. The support effect is shown in Figure 2(b).

\subsection{Complex Stress Field of the Roadway Surrounding Rock.} To reveal the stress environment of the roadway in the S2S2 workface, three observation stations of $P 1, P 2$, and $P 3$ were arranged at a distance of $50 \mathrm{~m}, 500 \mathrm{~m}$, and $1000 \mathrm{~m}$ away from the open-off cut, respectively, as shown in Figure 3(a). The stresses were measured by using the SYY -56 hydrofracturing in situ stress measurement device in the drilling of the roadway surrounding rock, as shown in Figure 3(b). The drilling depth was $10 \mathrm{~m}$ and the bore diameter was $56 \pm 2 \mathrm{~mm}$. The horizontal stresses on the two ribs and the vertical stresses on the roof are shown in Figure 3(c).

The results indicated that the rock stress varied with the positions along the roadway: at $P 1$ position, the stress on the two ribs $(21 \mathrm{MPa})$ is two times that of the roof $(10 \mathrm{MPa})$, while at $P 2$ position the roof stress $(21 \mathrm{MPa})$ is two times that of the ribs $(10 \mathrm{MPa})$, and when it turns to $P 3$ position, the right rib stress is the largest. It can be concluded that the rock stresses were not even around the roadway and changed along the length direction, and such high and uneven stress field far exceed the resistance of the surrounding rock which only has a saturated compressive strength of $3 \mathrm{MPa}-5 \mathrm{MPa}$, resulting in large displacement and damage depth of the roadway and high pressure on the support structures. Under the complex and uneven stress field at different positions, the 


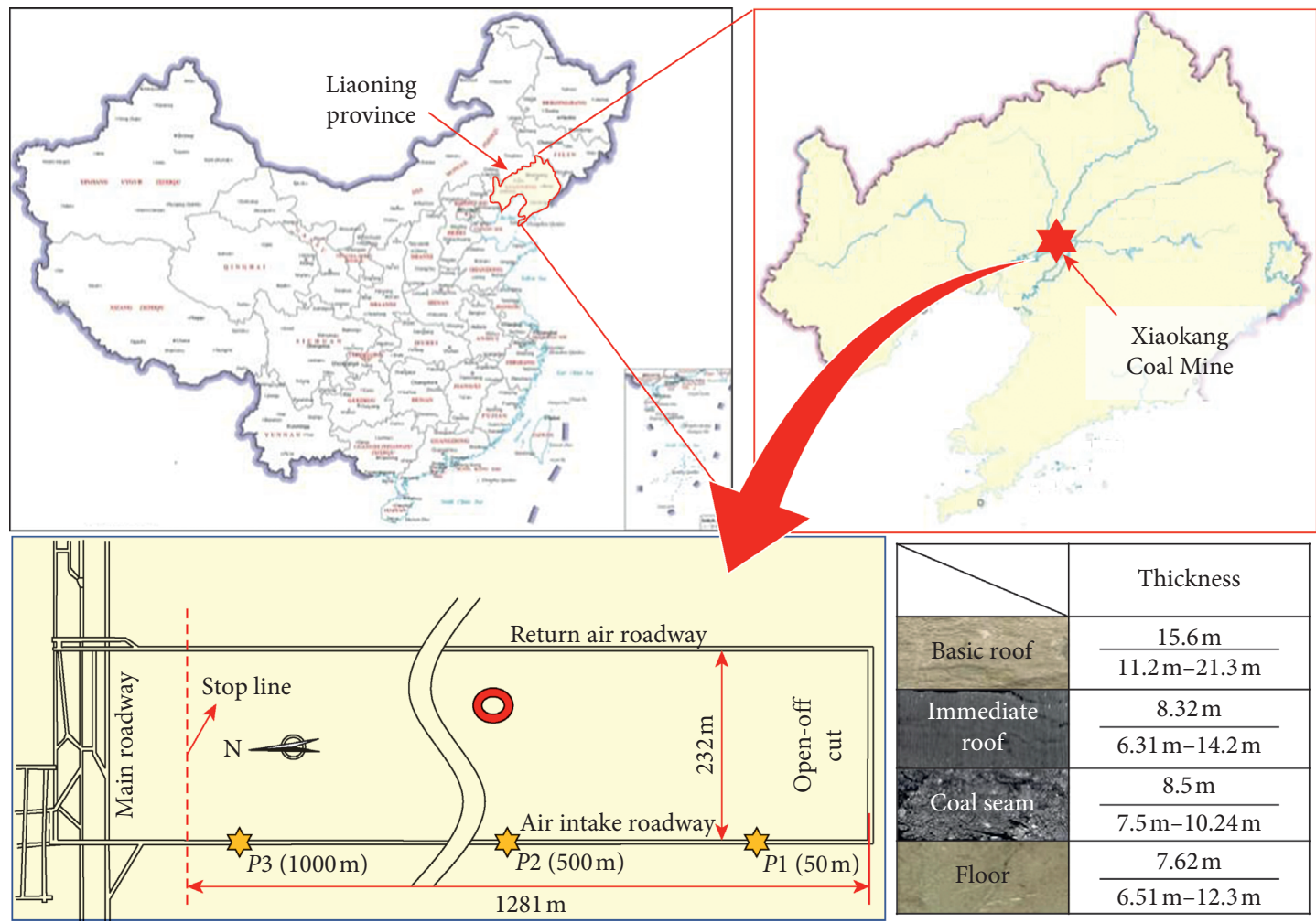

FIgURE 1: Location of the Xiaokang Coal Mine.

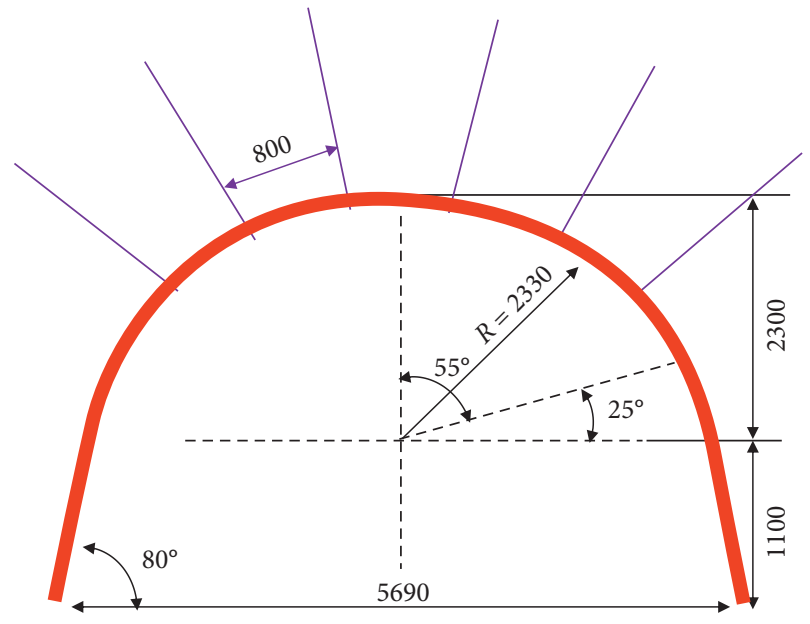

(a)

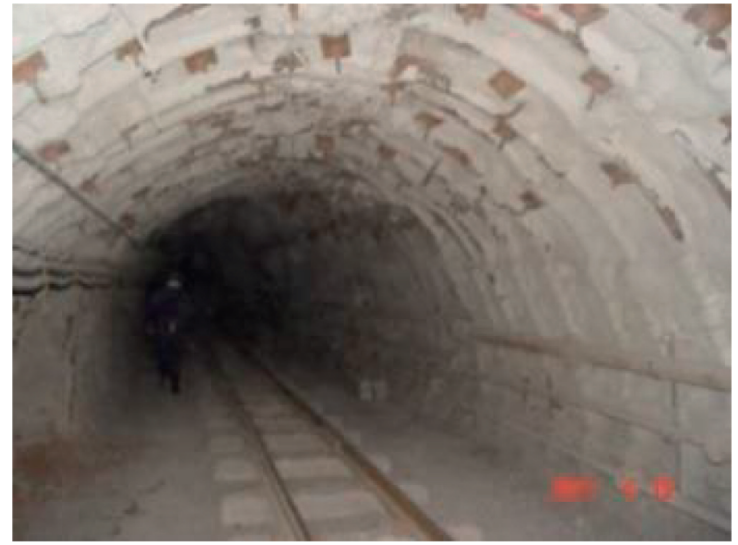

(b)

Figure 2: The original support. (a) Support parameters; (b) support effect.

performance of the U-shaped steel support will be simulated and analyzed in Section 3. In addition, in the new optimized support scheme, the selected U-shaped steel must adapt to such complex stress field environment which will be verified in Section 4.

2.4. The Roadway Deformation and Failure Characteristics. In order to analyze the roadway deformation and failure characteristics, three observation stations were set at observation stations of $P 1, P 2$, and $P 3$ to monitor the rib-to-rib convergence, roof separation, and floor heave during the stopping period under the influence of mining.

2.4.1. Displacement of Ribs. The crossing method is commonly used to measure the displacement of ribs, as shown in Figure 4 . The pegs were used to fix the ends of the line on two ribs, roof, and floor of the roadway at $P 1$ observation station (50 $\mathrm{m}$ away from the open-off cut). The surrounding rock on ribs moved inward towards the roadway under the actions of the horizontal stress causing the lateral displacement of the 


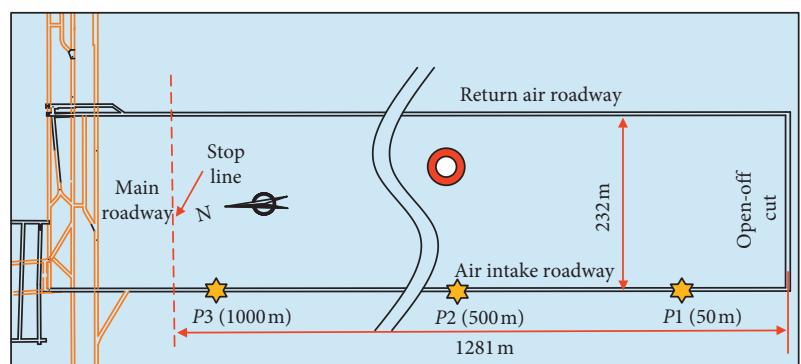

(a)

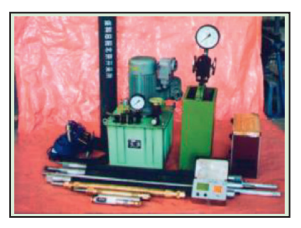

(b)

\begin{tabular}{|lccc|}
\hline $\begin{array}{l}\text { Measurement } \\
\text { position }\end{array}$ & Left rib & Right rib & Roof \\
\hline$P 1$ & 21 & 21 & 10 \\
$P 2$ & 10 & 10 & 21 \\
$P 3$ & 12 & 21 & 10 \\
\hline
\end{tabular}

(c)

Figure 3: In situ stress measurement of the roadway surrounding rock. (a) In situ stress measurement position. (b) In situ stress measuring device. (c) Stress measurement results.

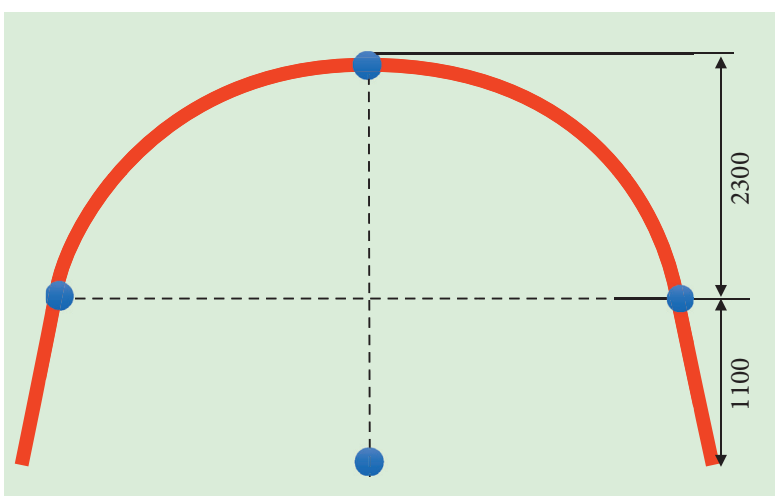

(a)

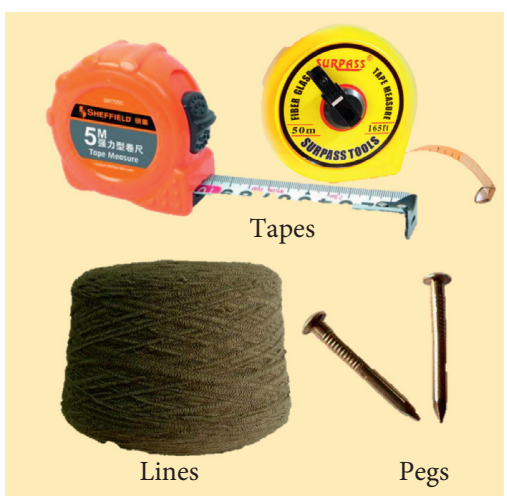

(b)

Figure 4: The monitoring scheme and devices.

surrounding rock. A tape was used to measure the displacement on ribs, as Figure 4(b). The monitoring results of rib-to-rib convergence are shown in Figure 5.

Figure 5 indicates that (1) there were three stages of ribto-rib convergence, that is, slow stage, accelerated stage, and instability stage, with the corresponding periods of $0 \sim 4$ days, 4 10 days, and 10 18 days, respectively; (2) the rib-to-rib convergence was $99 \mathrm{~mm}, 783 \mathrm{~mm}$, and $1300.5 \mathrm{~mm}$ in the three stages, respectively, and the total convergence was $2182.5 \mathrm{~mm}$, and the average speed was $138.9 \mathrm{~mm} / \mathrm{d}$ since 4 to 18 days; and (3) at the instability stage, the failure of the U-shaped steel support and the anchor bolt occurred and the roadway ribs were out of control.

2.4.2. Roof Separation. The roadway roof activities mainly include bending deformation, separation, and caving, which could be monitored by using the SMJ-2 roof separation device. The SMJ-2 is made up of anchor head of the base point, measuring line, casting, external cylinder, and internal cylinder. As shown in Figure 6(a), the roof separation device was mainly used to monitor the roof separation values within depths of $0-2.4 \mathrm{~m}$ and $0-8.0 \mathrm{~m}$ in the roof strata. The anchor head of the deep base point $(8.0 \mathrm{~m})$ was fixed within the stable deep bedrock, and the anchor head of the shallow base point $(2.4 \mathrm{~m})$ was fixed at the anchor end. The observation station was $500 \mathrm{~m}$ away from the open-off cut (i.e., P2 observation station).

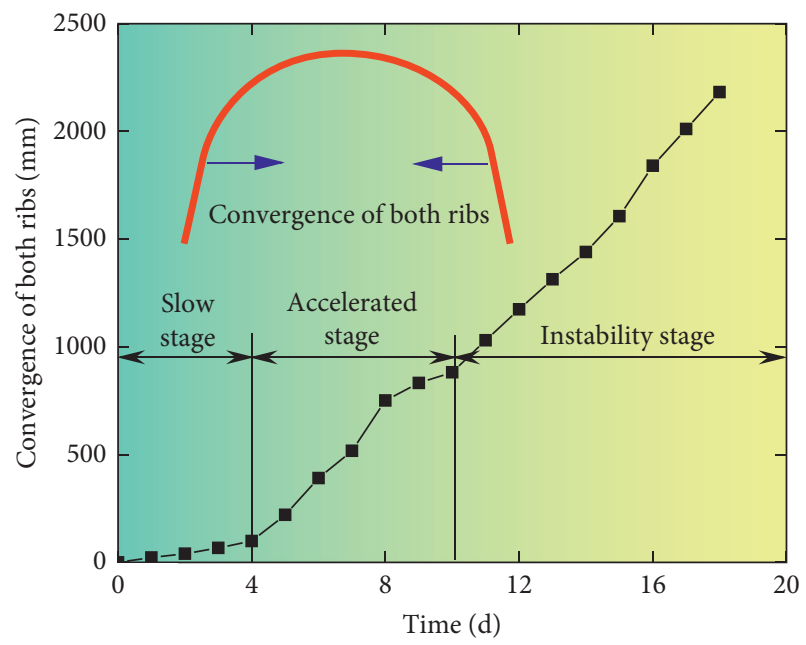

FIGURE 5: The rib-to-rib convergence.

The results of the shallow base points could be seen in Figure 6(b), which indicated that (1) the roadway roof experienced three stages, that is, the slow stage, accelerated stage, and stable stage with the periods of $0 \sim 4$ days, $4 \sim 11$ days, and 11 18 days, respectively; (2) the roof subsidence amounts were $101.6 \mathrm{~mm}, 843.4 \mathrm{~mm}$, and $84.0 \mathrm{~mm}$ at the three stages, respectively, and the total amount was 


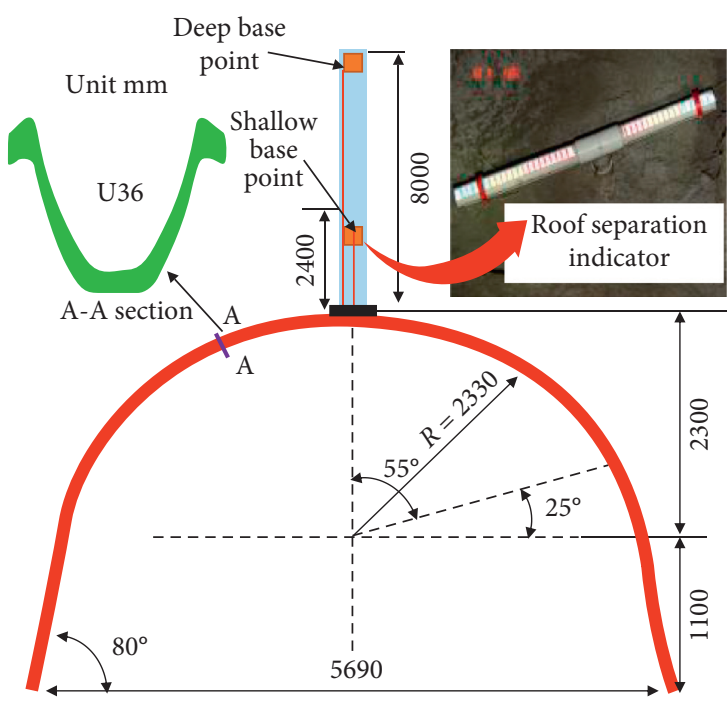

(a)

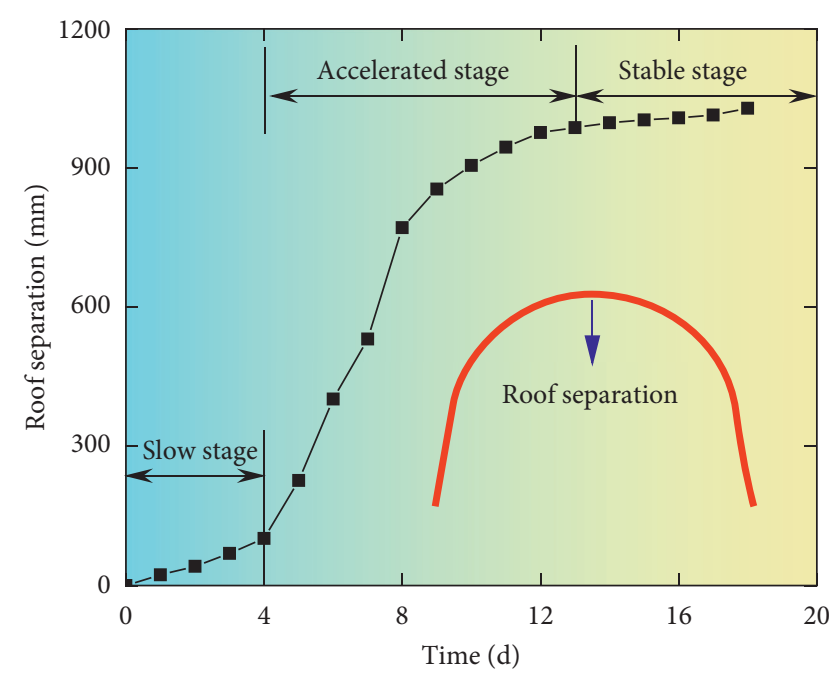

(b)

FIgURE 6: Roof separation. (a) The measurement scheme; (b) the results.

$1029 \mathrm{~mm}$; and (3) at the stable stage, the roof deformation basically kept unchanged because a single prop was used for timely maintenance.

\subsubsection{The Amount of Floor Heave. The floor heave is caused} by the uplift of the roadway floor due to mining, as shown in Figure 7 (a). It could reduce the roadway section, hinder the transportation and pedestrians, affect mine ventilation, and greatly limit the safe production of the mine. In the worst situation, the roadway has to be abandoned. To solve the severe floor heave, a lot of manpower and material resources are needed. The floor heave amounts were obtained $1000 \mathrm{~m}$ away from the cut-open, as shown in Figure 7(b).

Figure 7(b) indicates that (1) the roadway roof experienced three stages, that is, slow stage, accelerated stage, and stable stage with the periods of $0 \sim 6$ days, $6 \sim 15$ days, and 15 18 days, respectively; (2) the floor heave amounts were $168.0 \mathrm{~mm}, 828.0 \mathrm{~mm}$, and $48.8 \mathrm{~mm}$, respectively, at the three stages, and the total floor heave amount was $1044.8 \mathrm{~mm}$; and (3) at the stable stage, the floor deformation basically remained unchanged. As the original arched roadway adopted an open support system with no measurement to control the floor heave, the serious floor heave is mainly caused by stress extrusion and floor rock water expansion.

\section{Numerical Analysis of Deformation and Failure Characteristics of the U-Shaped Steel Support}

A shed is often used for soft-rock roadway support. In this support method, the bearing capacity of the U-shaped steel support is the basis to ensure the control effects of the roadway surrounding rock. When the loads applied on the U-shaped steel support exceed its bearing capacity, the support will undergo significant deformation and failure. According to the obtained roadway surrounding rock stresses in Section 2.3, the numerical simulation method was used to analyze the deformation and failure characteristics of the U-shaped steel support in this part.

\subsection{The Numerical Model}

3.1.1. The Constitutive Model of the Material. The materials of the U-shaped steel are usually $20 \mathrm{MnK}, 25 \mathrm{MnK}$, and $20 \mathrm{MnVK}$. According to the requirements of international standard GB/T228-2010, the aforementioned three materials were used to make tensile specimens with circular cross sections with a size of $100 \times \Phi 10 \mathrm{~mm}$ to conduct tensile tests at room temperature. The tensile testing machine is shown in Figure 8(a). It could realize automatic data acquisition, processing and storage, and real-time display of test status and curves.

Figure 8(b) shows the stress-strain curve of the specimens, which have undergone the elastic stage, yield stage, strengthened stage, and failure stage. The properties of the stress-strain curve were used to determine the materials' elastic modulus $E_{1}$, yield limit $\sigma_{s}$, and tensile limit $\sigma_{b}$. The bilinear isotropic hardening model was used to select the material type. The MATLAB was used to write program and fix the material's tangent modulus $E_{2}$. The electrical measurement method was applied to get the Poisson ratios $\mu$. Table 1 shows the detailed results.

3.1.2. Model Establishment. The establishment of the U-shaped steel support could be divided into the establishment of the solid model, the selection of the element type, the constitutive model of materials, and the boundary conditions. The specific process is as follows:

(1) The establishment of the solid model: according to the international standards of U-shaped steel, a 3D modeling software was applied to build an U36 section model, which was then saved in sat.file 


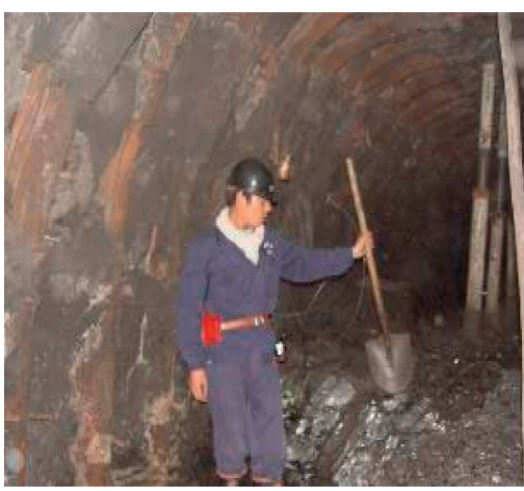

(a)

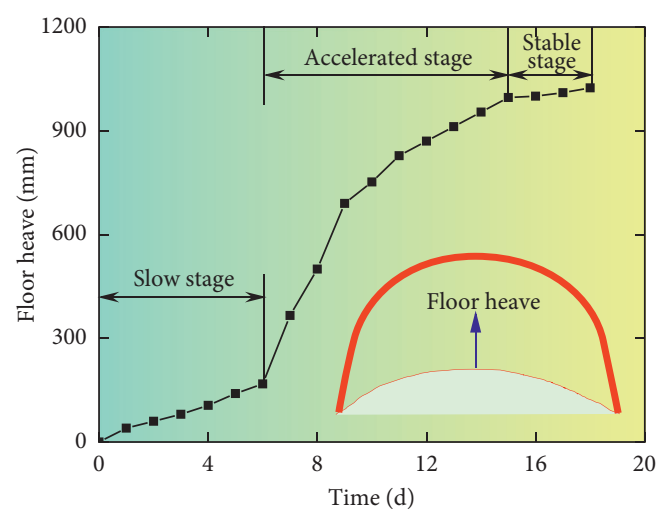

(b)

Figure 7: Roadway floor heave. (a) Floor heave; (b) floor deformation.

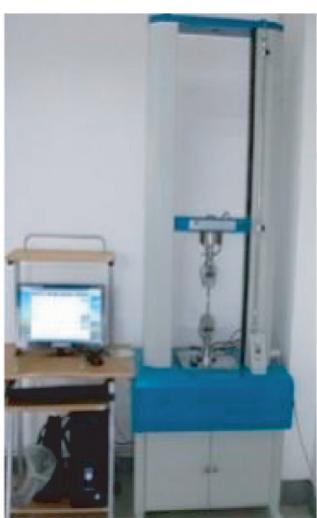

(a)

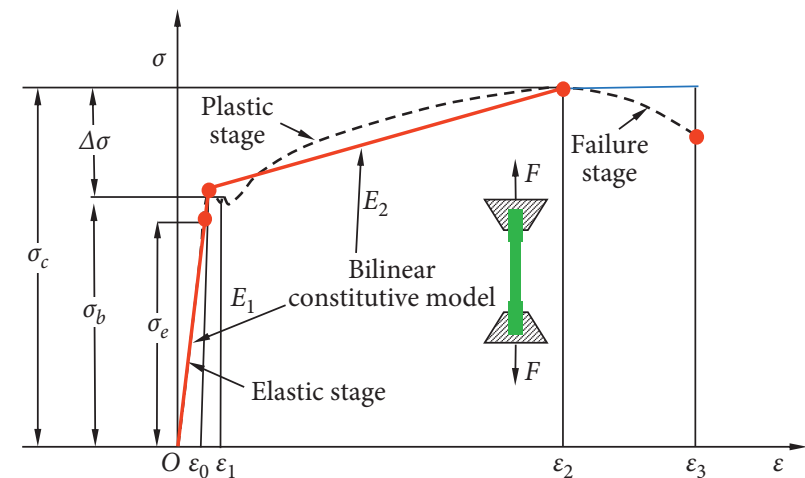

(b)

Figure 8: Pull-out test. (a) The synthetic material tensile testing machine; (b) the stress-strain curve.

TABLE 1: Main parameters of the U-shaped steel support.

\begin{tabular}{ccccccc}
\hline Type & Material & $\begin{array}{c}\text { Elastic modulus } \\
E_{1}(\mathrm{GPa})\end{array}$ & Poisson ratio $\mu$ & Tangent modulus $E_{2}(\mathrm{GPa})$ & Yield strength $\sigma_{s}(\mathrm{MPa})$ & Tensile strength $\sigma_{b}(\mathrm{MPa})$ \\
\hline $25 \mathrm{U}$ & $25 \mathrm{MnK}$ & 206 & 0.3 & 21 & 335 & 530 \\
$29 \mathrm{U}$ & $25 \mathrm{MnK}$ & 206 & 0.3 & 21 & 335 & 530 \\
$36 \mathrm{U}$ & $20 \mathrm{MnK}$ & 210 & 0.3 & 19 & 350 & 530 \\
$40 \mathrm{U}$ & $20 \mathrm{MnVK}$ & 215 & 0.3 & 20 & 390 & 580 \\
\hline
\end{tabular}

format and imported into the solver. Finally, the U-shaped steel support contour along the axial direction was constructed.

(2) The selection of the element type: the U-shaped steel support with shed is composed of a straight beam and a curved beam. Therefore, the straight beam element CBEAM and the curved beam element CBEAN were used in the numerical model. The former one required the neutral axis to coincide with the shear center and did not consider the effects of warping on the torsional stiffness as well as the influence of transverse shear [26]. The curved beam did not require the neutral axis to coincide with the shear center, and it also considered the impacts of warping on the torsional stiffness as well as the influence of transverse shear.

(3) The constitutive model of materials: based on the stress-strain curve of the pull-out test of the U-shaped steel support metal materials, the bilinear isotropic hardening elastic-plastic material model was selected. Table 1 shows the concrete parameters [28, 29].

(4) The boundary conditions: the constraint was simply supported at both ends [30-33]. According to the measured results of the roadway stress field obtained in Section 2.3, three types of the corresponding loads were applied on the axis of the U-shaped steel support. The above four steps were used to establish 
the U-shaped steel support numerical model, as shown in Figure 9.

3.2. The Deformation and Failure Characteristics. The deformation and failure characteristics of the U-shaped steel support at $P 1, P 2$, and $P 3$ observation stations were extracted and compared with field measurement, as shown in Figures 10(a)-10(c), respectively.

It could be obtained that

(1) The U-shaped steel support presented various deformation and failure characteristics under different stress states.

(2) As shown in Figure 10(a), the stresses on the two ribs of the roadway were greatly larger than the vertical stresses, which leads to the two sides of the U-shaped steel support being obviously moved inward at $P 1$ observation station. The maximum Mises stress was $440 \mathrm{MPa}$ at the leg of the shed. It was beyond the limit of the material and caused bending and failure.

(3) As shown in Figure 10(b), the vertical stresses on the top of the U-shaped steel shed were significantly larger than those on two legs, and obvious subsidence could be found on top of the U-shaped steel support at $P 2$ observation station, $500 \mathrm{~m}$ away from the cut-open. The maximum Mises stress was $463 \mathrm{MPa}$ at the top.

(4) As shown in Figure 10(c), the stresses on the right side of U-shaped steel shed were obviously larger than those on the left side, and the U-shaped steel support inclined to the left. The maximum Mises stress was $650 \mathrm{MPa}$ at the right side of the shed leg and caused bedding.

The analyses indicated that the arch roadway had poor adaptability under uneven and complex stress environment, and the stresses acted on the support by the surrounding rock exceeded its bearing capacity.

\section{Optimization and Design of Soft-Rock Roadway Support under Complex Stress Field}

As analyzed and discussed above, it is the precise factors such as the roadway being deep-buried, the surrounding rocks being weak and easy to expand and undergo weathering, the floor control not being included in the support system, the support structure not being able to fully mobilize the self-supporting capacity of surrounding rocks, the roadway section being unreasonable, etc., that finally cause the complex surrounding rock stress and the serious roadway deformation and failure.

In order to overcome the support difficulty of a deepburied soft-rock roadway, the floor heave control must be incorporated into the support system [34]. However, as previously discussed, in the initial open support system, the roadway was constructed with an arch section and the floor reinforcement and control was ignored, so the self-supporting capacity of surrounding rocks failed to be effectively

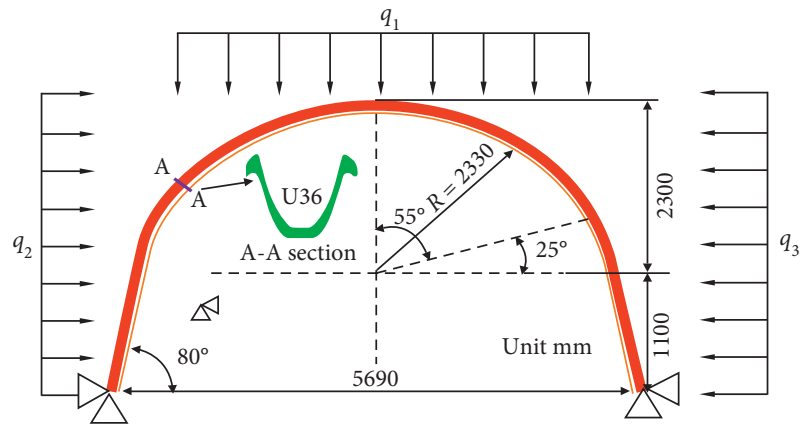

FIgURE 9: The numerical model of the arched U-shaped steel support.

manipulated and the support performance of the U-shaped steel could not be fully developed as analyzed in Section 3. Even if floor bolts were added later, the floor heave was still out of control.

Thus, aimed at overcoming the aforementioned support defects, which make the original supporting system unable to adapt to the deformation and failure characteristics of the deep-buried soft-rock roadway, it is critical to select an appropriate roadway section and improve the supporting system. According to the experience from the existing roadway support in Xiaokang Coal Mine, it is more reasonable for the roadway section to select circle than arch and ellipse. In order to reduce the actions of the surrounding rock on the support, the section size should be reduced as much as possible. To meet the minimum requirements of transportation and ventilation, the roadway section was designed with a diameter of $4.6 \mathrm{~m}$ and a net area of $13.9 \mathrm{~m}^{2}$.

Furthermore, matching with the redesigned circular roadway section, a new full-section combined support scheme of "belt-mesh-cable-shotcrete + U-shaped steel and wall back filling" was suggested, in which the positive support of the "belt-mesh-cable" could improve the selfsupporting ability of the surrounding rock, and the passive and rigid support of the "U-shaped steel and wall back filling" not only allows the roadway deformation in control to relieve the surrounding rock pressure, but also effectively resists excessive deformation to ensure that the roadway can be normally used. In this way, the new support system was expected to control the displacement and failure of such deep-buried soft-rock roadway.

4.1. Parameters of the U-Shaped Steel Support. To verify the bearing capacity of the U36 support with the diameter of $4.6 \mathrm{~m}$ under a complex stress field environment, the numerical simulation of the circular section U-shaped steel support was constructed. The in situ stress values obtained in Section 2.3 were applied.

As shown in Figure 11, when the circular section support was dominated by horizontal stress, vertical stress, and right horizonal stress, the corresponding deformation amounts were $465 \mathrm{~mm}, 636 \mathrm{~mm}$, and $763 \mathrm{~mm}$, respectively, and the maximum Mises stresses were $293 \mathrm{MPa}, 312 \mathrm{MPa}$, and $342 \mathrm{MPa}$, respectively. It implied that the circular U-shaped 


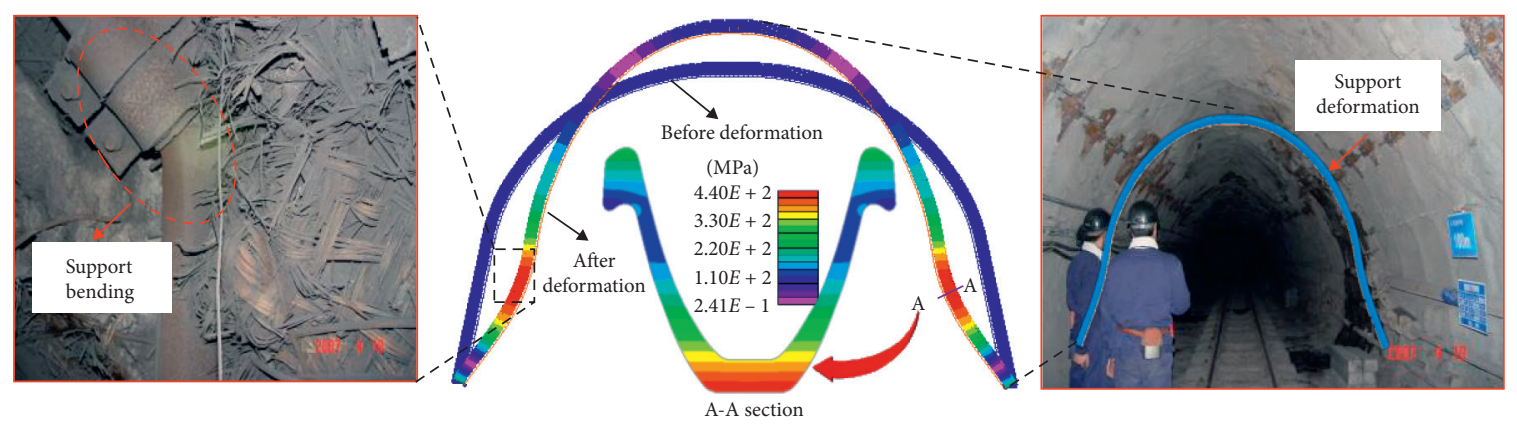

(a)

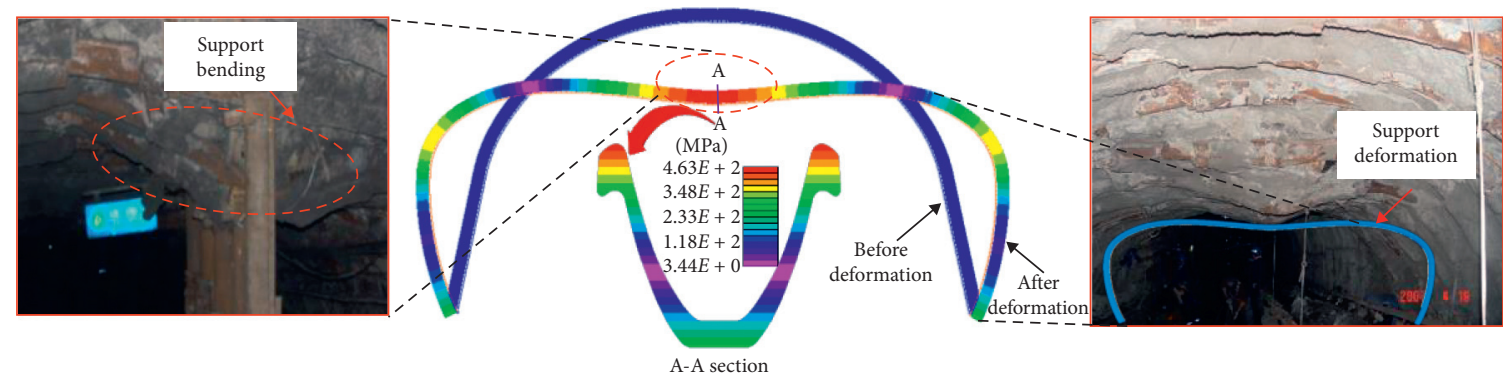

(b)
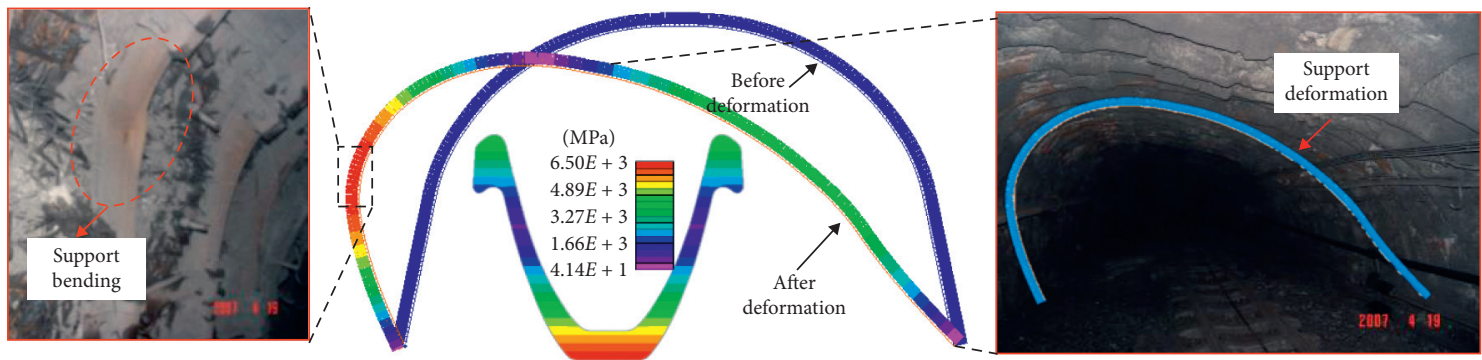

(c)

Figure 10: The deformation and failure characteristics of the U-shaped steel support. (a) At $P 1$ observation station, $50 \mathrm{~m}$; (b) at $P 2$ observation station, $500 \mathrm{~m}$; (c) at $P 3$ observation station, $1000 \mathrm{~m}$.

steel support had high ability to resist deformation, and the roadway deformation was well controlled to a certain degree.

4.2. The Filling behind the Support. During the process of construction, it is inevitable to leave a certain space between the U-shaped steel shed and the surrounding rock. Therefore, at the beginning, the shed almost has no support effect on the roadway, and its supporting resistance could not exert timely, resulting in the roadway deformation. Then, the surrounding rock will contact the U-shaped steel shed unevenly, leading the support to suffer extremely complex stress, which is manifested as the uneven distribution of the $\mathrm{U}$-shaped steel support load around the roadway and along the axial direction of the roadway. This is the main cause of bending, torsional deformation, and bearing capacity loss of the shed. However, the filling behind the shed support could eliminate such space, make the shed support and the surrounding rock come in close contact and make the shed suffer uniform load, so as to give full play to the supporting performance of the U-shaped steel shed.

The characteristics of the filling materials are as follows:
(1) The curing time of the filling materials should be short and the intensity should increase rapidly. That is, the filling materials should have certain early and later intensity.

(2) The filling materials should have certain compressibility. In the case of the surrounding rock deformation, the filling material could produce yielding effects.

(3) After curing, the filling materials should not undergo volume shrinkage, and they should have slight expansion.

(4) The filling materials should have abundant sources of raw materials, and also should be low-cost, easy to transport, and easy to construct underground.

(5) The filling materials should have favorable processing properties such as pumpability and timely support.

According to the above requirements and based on the existing engineering experience, the mixing proportions of the filling materials were given as follows: 


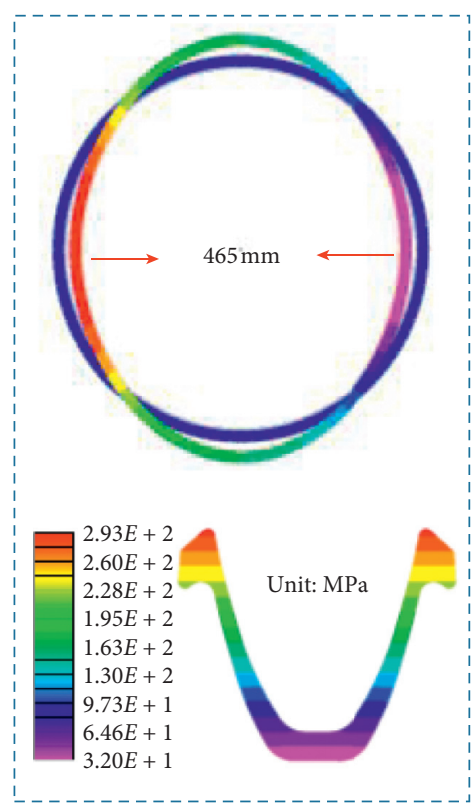

(a)

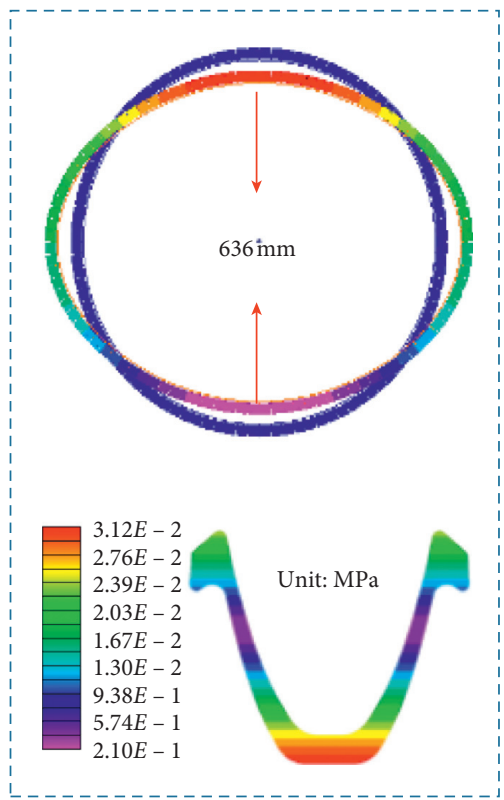

(b)

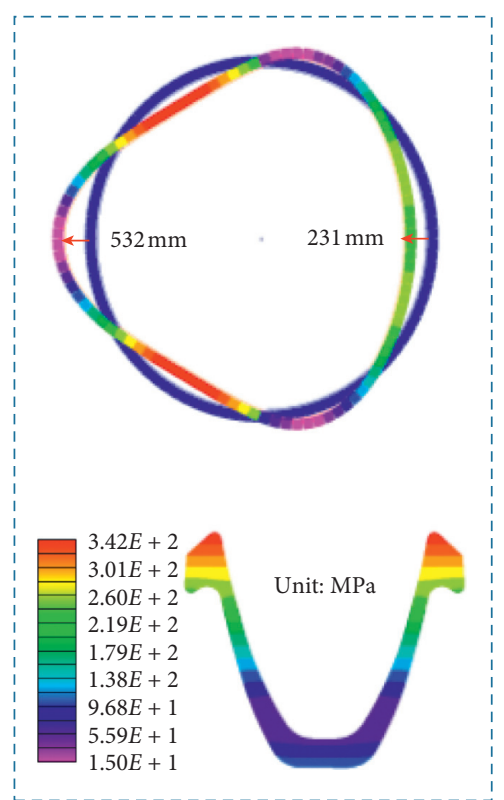

(c)

FIGURE 11: The deformation and failure laws of the circular section U-shaped steel support. (a) Horizontal stress, (b) vertical stress, and (c) horizontal unbalance loading.

(1) The raw materials of back wall filling consisted of cement, gypsum, coal ash, and plasticizer. The 425\# ordinary Portland cement and dihydrate gypsum were used [35-37]. The coal ash was the high-quality fly ash discharged from power plants.

(2) According to multiple trial ratios and on-site engineering experience, the cement-gypsum-coal ash ratio was $1: 1: 3$. The water-cement ratio was 0.4 . The admixture dosages accounted for $2 \%$ of the cement weight [38].

4.3. Parameters of Anchor Bolt and Cable. Another key to control the surrounding rock is to select the parameters of the anchor bolt and cable appropriately. Scholars have put forward many theories, such as the suspension theory and loose circle theory. These theories are useful to determine these parameters. In recent years, the prestress theory $[39,40]$ has been proposed, which suggests that a complete compressive stress layer within the surrounding rock of the roadway should be formed under the action of prestressed anchor bolt and prestressed anchor cable. The prestress theory has been generally accepted and has been widely used in industrial practice to provide basis for the determination of the anchor bolt and cable parameters.

According to the theory, without considering the original rock stress, if there exists a near-zero compressive stress layer within the supporting area of the anchor cable and bolt, it means that the bolt and cable fail to reinforce the surrounding rock in this area. If the compressive stress zones generated by different bolts and cables are isolated from each other, and a continuous ring of compressive stress is not formed, it means that the integral support effect of bolts and cables has not fully played [41-43]. Therefore, reasonable and effective bolt-cable support should generate as high compressive stress as possible within their support range, eliminate as much as possible the area of near-zero compressive stress, and make the area of compressive stress contiguous to form as large as possible the scale of compressive stress circle layer.

Thus, in order to clearly reflect the stress field generated by the prestressed anchor bolt and cable in the surrounding rock, the supporting effect is simulated numerically without considering the original rock stress, and the alternative support parameters are considered as shown in Figure 12: bolts with different spaces of $1200 \mathrm{~mm}, 1000 \mathrm{~mm}$, and $800 \mathrm{~mm}$, lengths of $1.8 \mathrm{~m}, 2.2 \mathrm{~m}$, and $2.4 \mathrm{~m}$, and pretightening forces of $40 \mathrm{kN}, 60 \mathrm{kN}$, and $100 \mathrm{kN}$, and cables with different lengths of $5.3 \mathrm{~m}, 6.3 \mathrm{~m}$, and $7.3 \mathrm{~m}$ and pretightening force of $60 \mathrm{kN}, 105 \mathrm{kN}$, and $150 \mathrm{kN}$. In addition, the simulation scheme is listed in Table 2.

As shown in Figure 12(a), under the pretightening force of $100 \mathrm{kN}$ and the length of $2.4 \mathrm{~m}$, with the decrease in the bolt support space from $1200 \mathrm{~mm}$ to $800 \mathrm{~mm}$, the compressive stress in the surrounding rock increases continuously, and the isolated compressive stress area begins to form a continuous compressive stress circle layer, and its range is obviously expanded outward. When the bolt spacing is $800 \mathrm{~mm}$, the continuous compressive stress circle layer has formed in the whole length of the bolt, and there is basically no near-zero compressive stress area and isolated compressive stress area. That is, the space of $800 \mathrm{~mm}$ is better than $1000 \mathrm{~mm}$ and $1200 \mathrm{~mm}$.

As shown in Figures 12(b) and 12(d), for both the anchor bolt and the cable, the increase in the pretightening force has a significant control effect on the magnitude of compressive 


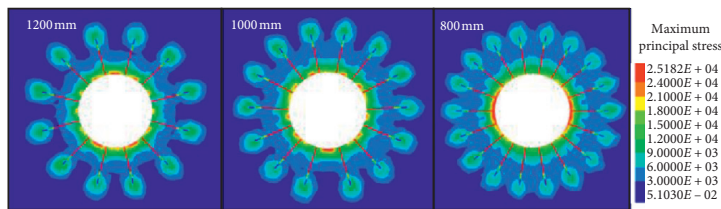

(a)

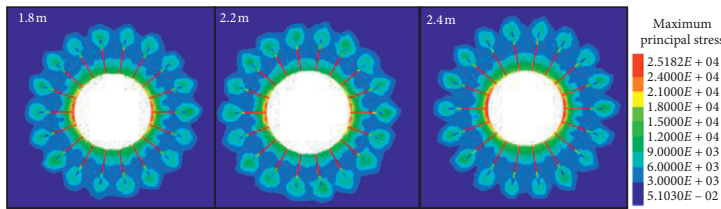

(c)

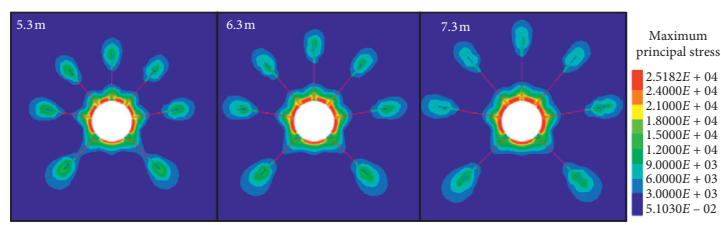

(e)

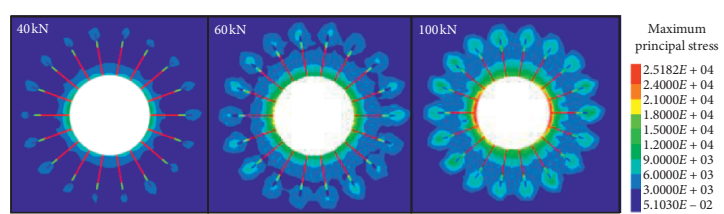

(b)

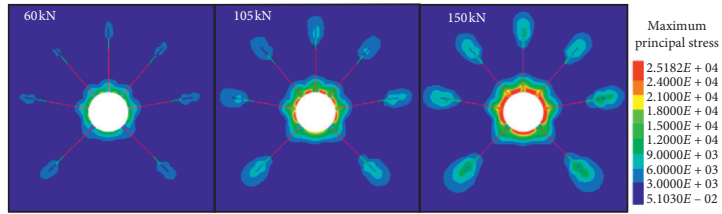

(d)

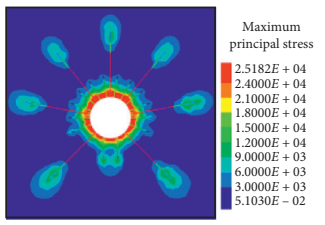

(f)

FIgURE 12: Parameter optimization of the anchor bolt and cable. (a) The space of the anchor bolt; (b) the pretightening force of the anchor bolt; (c) the length of the anchor bolt; (d) the pretightening force of the anchor cable; (e) the length of the anchor cable; (f) matching of bolts and cables.

TABLE 2: Simulation scheme for parameter optimization of the anchor bolt and cable.

\begin{tabular}{|c|c|c|c|c|}
\hline \multirow{2}{*}{ Support type } & \multirow{2}{*}{ Plans in Figure 12} & \multicolumn{3}{|c|}{ Parameters } \\
\hline & & Space $(\mathrm{mm})$ & Pretightening force $(\mathrm{kN})$ & Length $(\mathrm{mm})$ \\
\hline \multirow{3}{*}{ Anchor bolt } & (a) & $1200,1000,800$ & 100 & 2.4 \\
\hline & (b) & 800 & $40,60,100$ & 2.4 \\
\hline & (c) & 800 & 100 & $1.8,2.2,2.4$ \\
\hline \multirow{2}{*}{ Anchor cable } & (d) & - & $60,105,150$ & 7.3 \\
\hline & (e) & - & 150 & $5.3,6.3,7.3$ \\
\hline
\end{tabular}

stress and the range of a continuous compressive stress layer, so it is more appropriate to choose a higher pretightening force.

As shown in Figures 12(c) and 12(e), under the same pretightening force and support space, the length of the anchor bolt and cable has no significant effect on the improvement of the support effect. However, considering the complex geological conditions of soft rock and the existing support experience in this mine, it is suggested to choose the $2.4 \mathrm{~m}$ anchor bolt and $7.3 \mathrm{~m}$ anchor cable which have larger support range and higher safety coefficient.

According to the above simulation and analysis, the final support scheme is formed, that is, the anchor bolt with a length of $2.4 \mathrm{~m}$, an interval of $0.8 \mathrm{~m} \times 0.8 \mathrm{~m}$, and a pretightening force of $100 \mathrm{kN}$, and the anchor cable with a length of $7.3 \mathrm{~m}$, a pretightening force of $150 \mathrm{kN}$, an interval of $1.6 \mathrm{~m} \times 1.6 \mathrm{~m}$, and a density of 7 . The combined supporting effect of the anchor bolt and the cable is shown in Figure 12(f), and a complete compressive stress layer was formed around the roadway.

\section{Engineering Application}

5.1. The Scheme. First, instead of blasting, the road header was used to cut the roadway profile, which could reduce the impact of driving activities. Then, the anchor bolt and cable were applied. The diamond wire mesh was arranged on the roadway surface, and the U-shaped steel support shed was set. Finally, the filling behind the support was applied. The specific support parameters are shown in Figure 13.

U-shaped steel support: the diameter of the roadway section was $4.6 \mathrm{~m}$. 5 sets of U-shaped screw type connectors were set at each lap section. A set of strong draw plates was applied in the middle of the U-shaped steel to enhance the whole supporting capacity. The central angle of the round vault was $90^{\circ}$. To make the support have better bearing capacity and yieldable performance, the curvature radius $R_{1}$ of the vault should meet $N=R_{2} / R_{1}$. The curvature radius of the lateral arch was $R_{2}$. Therefore, when $N=1.0$, the support had the best bearing capacity, and the space between two sheds was $800 \mathrm{~mm}$. 


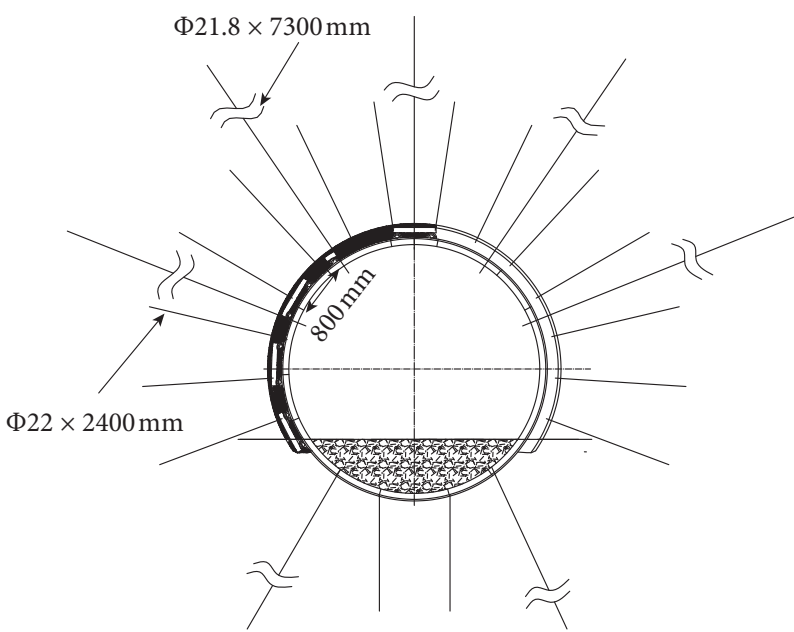

Figure 13: The scheme of the roadway support.

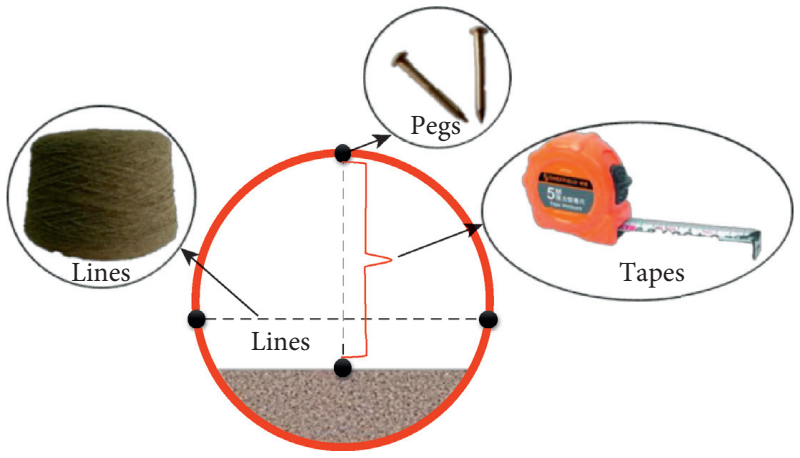

FIgURE 14: The monitoring scheme.

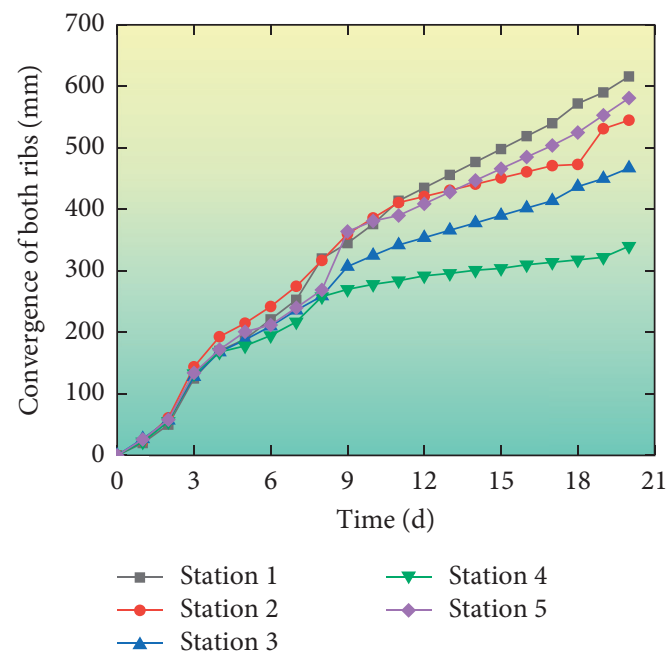

(a)

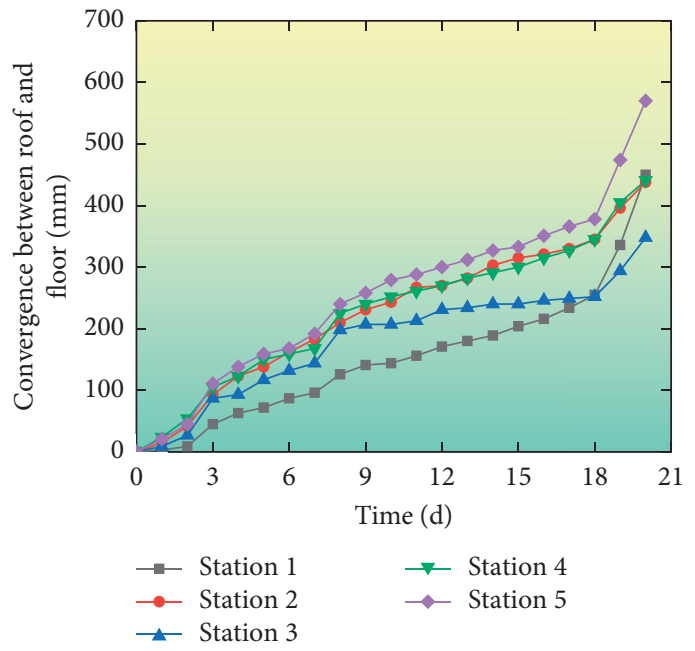

(b)

Figure 15: The roadway deformation under new support scheme. (a) Rib-to-rib convergence; (b) roof-to-floor convergence.

Anchor bolt: the left-hand threaded steel bolt without longitudinal reinforcement was used for the anchor bolt. The yield strength was $600 \mathrm{MPa}$ and the tensile strength was $800 \mathrm{MPa}$. The bolt had a diameter of $22 \mathrm{~mm}$ and a length of $2.4 \mathrm{~m}$. The interval of the bolt was $0.8 \mathrm{~m} \times 0.8 \mathrm{~m}$. The resin full-column anchorage was 
used, and the pretightening force of the bolt was $100 \mathrm{kN}$. The high-intensity tray was used with the size of $130 \mathrm{~mm} \times 130 \mathrm{~mm} \times 10 \mathrm{~mm}$.

Anchor cable: the anchor cable had a diameter of $21.8 \mathrm{~mm}$ and a length of $7.3 \mathrm{~m}$. The pretightening force of the anchor cable was $150 \mathrm{kN}$. A total of 7 cables were adopted. The high-intensity tray was used with the size of $300 \mathrm{~mm} \times 300 \mathrm{~mm} \times 16 \mathrm{~mm}$.

Shotcrete and filling behind the support: the first spraying thickness is $50 \mathrm{~mm}$, and the second spraying thickness is $100 \mathrm{~mm}$.

Other supports: the W-type steel band had a thickness of $4 \mathrm{~mm}$ and a width of $250 \mathrm{~mm}$. The self-made 10\# diamond metal net with a mesh spacing of $40 \mathrm{~mm} \times 40 \mathrm{~mm}$ was installed to protect the roof.

5.2. The Monitoring Scheme of the Roadway. In order to verify that the proposed new support method could effectively control the deformation and failure of the mining roadway with soft rocks under complex geological conditions, the roadway of the replacement workface of S2S2 FMCF in Xiaokang Coal Mine was taken as the example. 5 observation stations were distributed evenly in the roadway to monitor the surface displacement of the soft-rock roadway under the mining influence. The crossing method was also applied to monitor the rib-to-rib convergence and the roof-to-floor convergence. Figure 14 shows the specific monitoring method.

5.3. The Roadway Deformation Monitoring. The support quality of the roadway was judged by comparing the monitoring data with those of the original data. The underground roadway deformation was monitored continuously, and the rib-to-rib convergence and roof-to-floor convergence were monitored and given every other day, as shown in Figure 15.

Figure 15 indicates that

(1) Within 20 days of roadway monitoring, the rib-torib convergence was $616 \mathrm{~mm}, 545 \mathrm{~mm}, 467 \mathrm{~mm}$, $340 \mathrm{~mm}$, and $581 \mathrm{~mm}$ from No. 1 to No. 5 observation points, respectively. That of original support scheme was $2182.5 \mathrm{~mm}$. Therefore, the deformation of the ribs was effectively controlled.

(2) Within 20 days of roadway monitoring, the roof-tofloor convergence was $450 \mathrm{~mm}, 438 \mathrm{~mm}, 348 \mathrm{~mm}$, $441 \mathrm{~mm}$, and $570 \mathrm{~mm}$ from No. 1 to No. 5 observation points, respectively. Compared with the original support scheme with a roof separation of $1029 \mathrm{~mm}$ and a floor heave of $1044.8 \mathrm{~mm}$, the roadway roof and floor deformations were well controlled.

The obtained roadway deformation laws verify that the new support scheme could effectively control the surrounding rock deformation.

\section{Conclusions}

Based on the on-site monitoring and numerical simulation of the original roadway support effect, the U-shaped steel support, the anchor cable, and the bolt were optimized and verified, a new full-section combined support system of "belt-cable-mesh-shotcrete and U-shaped steel-filling behind the support" was proposed, and the support effects were simulated and in situ measured. The main conclusions are as follows:

(1) The roadway in the S2S2 working face underwent serious deformation and damage with a rib-to-rib convergence of $2183 \mathrm{~mm}$, a roof separation of $1029 \mathrm{~mm}$, and a floor heave of $1045 \mathrm{~mm}$. In addition, it was the overload pressure that caused the failure of the U-shaped steel support.

The in situ measurement and simulation results indicated that it was the unreasonable roadway section and the failure control of the floor heave that weakened the self-supporting capacity of the surrounding rock, caused the complex surrounding rock stress, and finally resulted in the failure of the initial soft-rock roadway support.

(2) For optimization, the roadway section in the replacement FMCF was changed from arch to circle and a new full-section combined support scheme of "belt-cable-mesh-shotcrete and U-shaped steel-filling behind the support" was proposed.

The redesigned U-shaped steel support was verified by simulation and it exhibited high adaptability to different types of surrounding rock stress, and the roadway deformation could be effectively controlled within $770 \mathrm{~mm}$. The support parameters of the belt and cable were determined by simulation with the pretightening theory.

(3) The optimized full-section combined support scheme was practiced and applied in the roadway of the replacement FMCF. In addition, the in situ measured rib-to-rib convergence and roof-to-floor convergence were both controlled within $600 \mathrm{~mm}$, i.e., the roadway deformation and failure were controlled effectively.

\section{Data Availability}

The data used to support the findings of this study are included within the article.

\section{Conflicts of Interest}

The authors declare that they have no conflicts of interest.

\section{Acknowledgments}

This work was supported by the Fundamental Research Funds for the Central Universities (2017BSCXB50) and Postgraduate Research \& Practice Innovation Program of 
Jiangsu Province (KYCX17_1528). The authors gratefully acknowledge the financial support from the organization.

\section{References}

[1] J. P. Bennett, B. W. Riggs, K. S. Kwong, and J. Nakano, "Mechanisms of Wear Reduction in High Chrome Oxide Refractories Containing Phosphate Additions Exposed to Coal Slag," John Wiley \& Sons, Ltd., Hoboken, NJ, USA, 2014.

[2] S. Bhaskaran, A. Ganesh, S. Mahajani, P. Aghalayam, R. K. Sapru, and D. K. Mathur, "Comparison between two types of Indian coals for the feasibility of underground coal gasification through laboratory scale experiments," Fuel, vol. 113, pp. 837-843, 2013.

[3] D. Ma, H. Duan, X. Li, Z. Li, Z. Zhou, and T. Li, "Effects of seepage-induced erosion on nonlinear hydraulic properties of broken red sandstones," Tunnelling and Underground Space Technology, vol. 91, Article ID 102993, 2019.

[4] C. H. An, G. B. Zhang, Z. D. Liu, K. Zhao, W. Guo, and H. L. Liu, "Deformation failure analysis and stability control technology of large section soft rock chamber in deep coal mine," Applied Mechanics and Materials, vol. 353-356, pp. 1035-1039, 2013.

[5] N. Zhang, J. B. Bai, J. Y. Zhou, X. M. Cheng, Z. L. Zhu, and L. C. Chang, "Strata control technology by grouting in soft rock roadway," Rock Mechanics Symposium, vol. 5, 2001.

[6] D. Ma, H. Duan, J. Liu, X. Li, and Z. Zhou, "The role of gangue on the mitigation of mining-induced hazards and environmental pollution: an experimental investigation," The Science of the Total Environment, vol. 664, no. 10, pp. 436-448, 2019.

[7] H. A. Lazemi, M. Fatehi Marji, A. R. Yarahmadi Bafghi, and K. Goshtasbi, "Rock failure analysis of the broken zone around a circular opening/analiza pęknięcia skały w strefie naruszonej wokół otworu kolistego," Archives of Mining Sciences, vol. 58, no. 1, pp. 165-188, 2013.

[8] C. O. Aksoy, M. Geniş, G. Uyar Aldaş, V. Özacar, S. C. Özer, and Ö. Yilmaz, "A comparative study of the determination of rock mass deformation modulus by using different empirical approaches," Engineering Geology, vol. 131-132, pp. 19-28, 2012.

[9] P. Hamdi, D. Stead, and D. Elmo, "Characterizing the influence of stress-induced microcracks on the laboratory strength and fracture development in brittle rocks using a finite-discrete element method-micro discrete fracture network FDEM- $\mu$ DFN approach," Journal of Rock Mechanics and Geotechnical Engineering, vol. 7, no. 6, pp. 609-625, 2015.

[10] D. H. Wu, W. G. Qiao, W. J. Song, and P. Vladimir, "Research on secondary support time of soft rock roadway," Journal of China Coal Society, vol. 40, pp. 5-10, 2016.

[11] J. L. Zhao, P. Song, B. Z. Liu, K. Tian, and L. R. Liu, "Study on stagger arrangement roadway layout under the condition of high stress soft rock in the medium-thickness coal seam," in Proceedings of the International Conference on New Energy and Renewable Resources (ICNERR), Guangzhou, China, 2015.

[12] D. Ma, J. Zhang, H. Duan et al., "Reutilization of gangue wastes in underground backfilling mining: overburden aquifer protection," Chemosphere, vol. 264, no. 1, Article ID 128400, 2021.

[13] M. C. He, H. H. Jing, and X. M. Sun, Engineering Mechanics of Soft Rock, Science Press, Beijing, China, 2002.

[14] H. P. Kang and J. H. Wang, Rock Bolting Theory and Complete Technology for Coal Roadways, China Coal Industry Publishing House, Beijing, China, 2007.
[15] Y. F. Gao, B. Wang, J. Wang et al., “Test on structural property and application of concrete-filled steel tube support of deep mine and soft rock roadway," Chinese Journal of Rock Mechanics and Engineering, vol. 29, no. s1, pp. 2604-2609, 2010.

[16] Y. D. Jiang, Y. X. Zhao, W. G. Liu, and Q. Li, "Research on floor heave of roadway in deep mining," Chinese Journal of Rock Mechanics and Engineering, vol. 23, no. 14, pp. 23962401, 2004.

[17] S.-Q. Yang, M. Chen, H.-W. Jing, K.-F. Chen, and B. Meng, "A case study on large deformation failure mechanism of deep soft rock roadway in xin'An coal mine, China," Engineering Geology, vol. 217, pp. 89-101, 2017.

[18] B. Shen, "Coal mine roadway stability in soft rock: a case study," Rock Mechanics and Rock Engineering, vol. 47, no. 6, pp. 2225-2238, 2014.

[19] H. P. Kang, J. Lin, and M. J. Fan, "Investigation on support pattern of a coal mine roadway within soft rocks - a case study," International Journal of Coal Geology, vol. 140, pp. 31-40, 2015.

[20] L. G. Wang, H. L. Li, and J. Zhang, "Numerical simulation of creep characteristics of soft roadway with bolt-grouting support," Journal of Central South University of Technology, vol. 15, no. 1, pp. 391-396, 2008.

[21] H. J. Zhang, H. Y. Li, S. C. Li, J. W. Bai, T. Y. Hao, and H. W. Li, "Deformation mechanism of surrounding rock and support technology in deep soft rock roadway," Journal of Mining and Safety Engineering, vol. 32, no. 6, pp. 955-962, 2015.

[22] P. Song, J. L. Zhao, and T. Xue, "Studying the reasonable roadway layout under the condition of high stress soft rock," in Proceedings of the 5th International Conference on Advanced Design and Manufacturing Engineering, pp. 14821485, Atlantis Press, Shenzhen, China, September 2015..

[23] Y. Huang, J. Li, D. Ma, H. Gao, Y. Guo, and S. Ouyang, "Triaxial compression behaviour of gangue solid wastes under effects of particle size and confining pressure," The Science of the Total Environment, vol. 693, Article ID 133607, 2019.

[24] C. Lu, C. Zang, F. Yu, and X. Yu, "Optimization on gateway section of soft coal seam and hard roof and supporting technology," Applied Mechanics and Materials, vol. 90-93, pp. 622-625, 2011.

[25] H. Bei, Y. Z. Xia, R. I. Barabash, and Y. F. Gao, "A tale of two mechanisms: strain-softening versus strain-hardening in single crystals under small stressed volumes," Scripta Materialia, vol. 110, pp. 48-52, 2016.

[26] F. Tonon, "ADECO full-face tunnel excavation of two $260 \mathrm{~m} 2$ tubes in clays with sub-horizontal jet-grouting under minimal urban cover," Tunnelling and Underground Space Technology, vol. 26, no. 2, pp. 253-266, 2011.

[27] D. Ma, H. Duan, W. Liu, X. Ma, and M. Tao, "Water-sediment two-phase flow inrush hazard in rock fractures of overburden strata during coal mining," Mine Water and the Environment, vol. 39, no. 2, pp. 308-319, 2020.

[28] S. H. Yang and S. Y. Wang, "Application of coupling support in soft rock mining roadway," Journal of Coal Technology, vol. 27, no. 5, pp. 53-56, 2008.

[29] H. Yan, J.-x. Zhang, L.-y. Li, and R.-m. Feng, "Stability assessment of rock surrounding an I-beam supported retreating roadway," Journal of Central South University, vol. 22, no. 9, pp. 3598-3607, 2015.

[30] Y. Tai, X. Han, P. Huang, and B. F. An, "The mining pressure in mixed workface using a gangue backfilling and caving method," Journal of Geophysics and Engineering, vol. 16, no. 1, pp. 1-15, 2019. 
[31] Y. Tai, S. Guo, and B. F. An, "The influence of gangue particle size and gangue feeding rate on the dynamic response of suspended buffer and engineering application," Journal of Geophysics and Engineering, vol. 16, no. 2, pp. 275-288, 2019.

[32] D. Ma, H. Y. Duan, Q. Zhang et al., "A numerical gas fracturing model of coupled thermal, flowing and mechanical effects," Computers, Materials le Continua, vol. 65, no. 3, pp. 2123-2141, 2020.

[33] D. Ma, J. J. Wang, X. Cai et al., "Effects of height/diameter ratio on failure and damage properties of granite under coupled bending and splitting deformation," Engineering Fracture Mechanics, vol. 220, Article ID 106640, 2019.

[34] Y. Tai, F. Ju, and X. L. Han, "Investigation of the kinetic energy transformation pattern of gangue particles in a buffer system," Powder Technology, vol. 344, pp. 926-936, 2019.

[35] Y. Tai, S. Guo, B. F. An, and F. Ju, "Analysis of the nonlinear dynamic response of guide rails for a suspended buffer," PLOS One, vol. 14, Article ID e210185, 2019.

[36] F. S. Zhang, X. Y. Xie, and H. W. Huang, "Application of ground penetrating radar in grouting evaluation for shield tunnel construction," Tunnelling and Underground Space Technology, vol. 25, no. 2, pp. 99-107, 2010.

[37] S. Swedenborg and L. O. Dahlström, "Rock mechanics effects of cement grouting in hard rock masses," in Proceedings of the 3rd International Conference: Grouting and Ground Treatment, pp. 1089-1102, New Orleans, Louisiana, February 2003.

[38] D. J. Pan, N. Zhang, C. H. Zhang, D. Qian, C. L. Han, and S. Yang, "Long-term mechanical behavior of nano silica sol grouting," Nanomaterials, vol. 8, no. 1, 2018.

[39] Y. G. Hu, R. Li, X. X. Wu, G. Zhao, and Q. L. Zhang, "Blasting damage depth in layered jointed basalt before and after grouting," Journal of Geotechnical and Geoenvironmental Engineering, vol. 145, no. 3, Article ID 4018113, 2019.

[40] H. S. Tu, S. H. Tu, C. Wang, D. Y. Hao, and D. F. Zhu, "Mechanical analysis of a vertical-wall, semicircular-arch roadway and a repair technique using double-shell support," Environmental Earth Sciences, vol. 77, no. 13, 509 pages, 2018.

[41] H. P. Kang, T. M. Jiang, and F. Q. Gao, "Effect of pre-tensioned stress to rock bolting," Journal of China Coal Society, vol. 32, no. 7, pp. 680-685, 2007.

[42] H. P. Kang, T. M. Jiang, and F. Q. Gao, "Design for pretensioned rock bolting parameters," Journal of China Coal Society, vol. 33, no. 7, pp. 721-726, 2008.

[43] J. Z. Li, H. P. Kang, F. Q. Gao, and J. F. Lou, “Analysis of bolt support stress field and bolt support effect under in-situ stress field," Journal of China Coal Society, vol. 45, no. s1, pp. 99109, 2020. 